\section{Endoscopic Treatment of Gallstone-Impacted Choledochocele Precisely Diagnosed by Endoscopic Ultrasonography}

We present here a rare case of choledochocele (1) in association with an impacted gallstone leading to obstructive jaundice, which was diagnosed by endoscopic ultrasonography (EUS) and treated endoscopically.

A 70-year-old lapanese man. who had been diagnosed as having choledochecele with gallbladder debris six months previously, was readmitted due to fever and jaundice. The laboratory data showed a total bilirubin level of $9.2 \mathrm{mg} / \mathrm{dl}$ (direct bilirubin $6.6 \mathrm{mg} / \mathrm{ml}$ ). EUS demonstrated that there was an impact gallstone. $9 \mathrm{~mm}$ in diameter in the choledochocele. The intramural roof of the choledochocele was thickened (Figure 1). However, gallbladder debris previously noted on EUS had disappeared. We assumed that the gallbladder debris had migrated into the common bile duet and then became impacted in the choledochocele. An endoscopic incision of the intramural roof of the choledochocele and sphincterotomy was therefore performed. A gallstone was extracted using a basket catheter (Figure 2). The postoperative course was uneventful, with resolution of the jaundice and a decrease in the total bilirubin level.

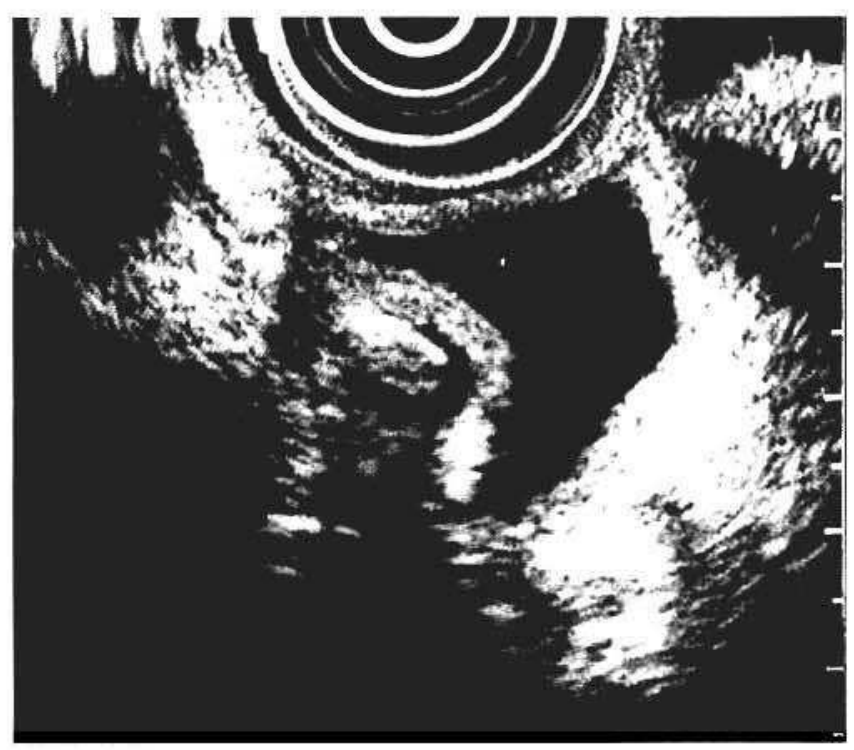

Figure 1: EUS stownag a choledochocele with an impart qallsione $9 \mathrm{~mm}$ in diameter, and the thickened intramural soof of the cholersochorcle. 


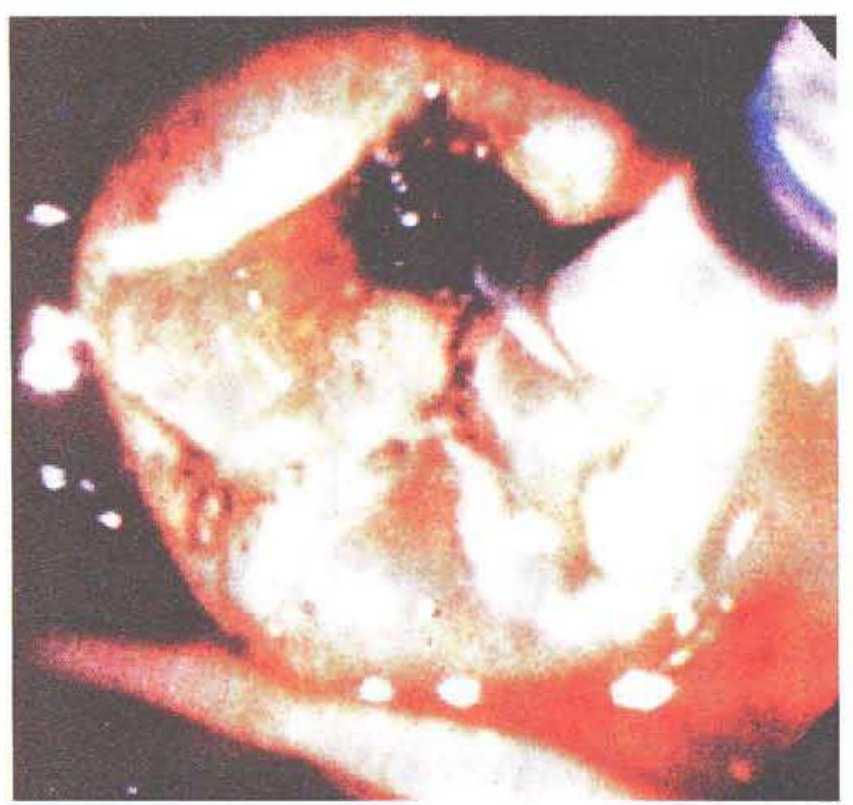

Figure 2: Endoscopic incision of the intramural roof of the choledochocele and sphincterotomy were carried out. The gallstone was then extracted endoscopically with a basket catheter.

The management of choledochocele with an impact gallstone has not previously been reported in the literature; the present case showed that endoscopic therapy can be successful. Although the indications for endoscopic management of symptomatic choledochocele are still controversial $(2-4)$, in our case it was safe, effective, efficient, and resulted in a short hospitalization period.
S. Tanno, H. Maguchi, T. Obara, T. Fujii, S. B. Santos, A. Itoh, N. Nishino, S. Arisato, H. Ura, Y. Kohgo

Dept. of Internal Medicine III, Asahikawa Medical College, Asahikawa, Japan

\section{References}

1. Alonso-Lej F, Rever WB Jr, Ressagno DJ. Congenital choledochal cyst, with a report of 2 , and an analysis of 94 , cases. Int Abstr Surg 1959; 108: 1-30.

2. Venu RP, Greenen JE, Hogan WJ, et al. Role of endoscopic retrograde cholangiopancreatography in the diagnosis and treatment of choledochocele. Gastroenterology 1984; 87: 1144-9.

3. Martin RF, Biber BP, Bosco JJ, et al. Symptomatic choledocheoceles in adults: endoscopic retrograde cholangiography recognition and management. Arch Surg 1992; 127: 536-9.

4. Lopez RR, Pinson CW, Campbell JR, et al. Variation in management based on type of choledochocele cysts. Am J Surg 1991; 161: $612-5$.

\section{Corresponding Author}

S. Tanno, M. D.

Dept. of Internal Medicine III Asahikawa Medical College 4-5-3-11 Nishikagura Asahikawa

Hokkaido 078

Japan

Fax: $+81-166-65-5183$ 